occur without any sinking of the land or rising of the sea. And I, for one, agree with Mr. Kinahan, that they are "submerged" at the present day, in so far that they are below the level suitable to the growth of trees, of the kinds of which they consisted. A singular fact about these old forests that requires explanation is their almost universal occurrence at a certain uniform level of flat land. It might otherwise have been expected, under these circumstances, that they would have grown upon a surface of silt, deposited by water action. But, as far as my observation goes, they usually grew upon the clay, which forms the bed rock of the locality. At Selsey it is distinctly weathered." How came these tracts of uniform level to exist at so many localities?

At some places, however, there is a gravelly bed beneath the forest, and, in such, at Barnstaple occur flint knives.

There is a submarine forest at a much lower level indicated in Mr. Godwin-Austen's paper first referred to (section no. 1, pl. vi.), which must, I think, belong to a period antecedent to that of the forests of which I have been speaking.

I would take the liberty of referring upon the above and kindred topics to my paper on "The Warp," in the Journal of the Geological Society, vol. xxii. p. 553 .

Hariton Regtoby, Cambridae.

o. Fishrir.

\title{
A VOICE FROM THE PAST.
}

SrR,-I suppose there has been no more thorough and accurate observer of geological phenomena than the late Prof. Sedgwick. On going through his papers of nigh half a century ago, on the English Lake District, I am constantly struck with his minuteness of investigation, and his careful and logical deductions. Had he been blessed with a good ordnance map, there would have been comparatively little general work left for the Geological Survey to accomplish. The following extract from one of the late Professor's letters, dated May 24th, 1842, is interesting in the present day, when land-ice is supposed by some to have been equal to any task:- "No ene will, I trust, be so bold as to affirm that an uninterrupted glacier could ever have extended from Shap Fells to the coast of Holderness, and borne along the blocks of granite through the whole distance, without any help from the floating power of water. The supposition involves difficulties tenfold greater than are implied in the phenomenon it pretends to account for. The glaciers descending through the valleys of the higher Alps have an enormous transporting power: but there is no such power in a great sheet of ice expanded over a country without mountains, and at a nearly. dead level."

The various Arctio voyages made of late years have shown that the drifting of pack-ice is more often due to winds of constant direction acting upon the many slight irregularities of the ice, than to currents affecting great thicknesses of the watery strata below.

1 See the writer's paper on Bracklesham Bed, Journ. Geol. Soc. vel. xniii. p. 74, note. 
Perhaps this has scarcely been taken into sufficient account by those who have considered the transportation of boulders by floating-ice. If there really was a considerable mid-glacial submergence-of which I cannot but think there is ample evidence both in Cumbria and in Wales-is it not quite possible that westerly winds prevailed at certain seasons, which might drift large quantities of boulderbearing ice from the Shap district without the aid of permanent ocean-currents? The difficulties involved in the theories of Messrs. Croll, Belt, Goodchild, and others of the same extreme school, certainly press upon me--and I think I may say also upon others of my colleagues-increasingly, as the country becomes more and more familiar in its features. It is indeed a most startling thought, as one stands upon the eastern borders of the Lake-mountains, to fancy the ice from the Scotch hills stalking boldly across the Solway, marching steadily up the Eden Valley, and persuading some of the ice from Shap to join it on an excursion over Stainmoor, and bring its boulders with it.

The outlying northern parts of the Lake-district, and the flat country beyond, have indeed been ravaged in many a raid by our Scotch neighbours, but it is a question whether, in glacial times, the Cumbrian mountains and Pennine shain had not strength in their protruding icy arms to keep at a distance the ice proceeding from the district of the southern uplands, the mountains of which are not superior in elevation. Let us hope that the careful geological observations which will doubtless be made in the forthcoming scientific Arctic Expedition will throw much new light on our past glacial period.

KBswICK, April 26th, 1875.

J. Chifton Ward.

\section{THE MECHANISM OF STROMBOLI. ${ }^{1}$}

Srr,-It is quite immaterial to the validity of the mechanism of Stromboli which I have suggested (Proc. Roy. Soc. 1874) whether the bottom of the crater be 300 to 400 feet, or be 2,000 feet above the sea-level, as no physicist reading the above paper can fail to see.

WestuInstre, 19 May, 1875.

Roвt. Madiet.

\section{SPHENONCHUS HAMATUS, A RH ATIC FOSSIL.}

SrR,-I beg to record my discovery a few days since of a large Sphenonchus, in the bone-bed of Aust Cliff, a genus hitherto unknown in the Rhrtic formation. I have compared it with a specimen of S. hamatus in the Bristol Museum, obtained from the Blue Lias at Keynsham, (an unrecorded find, by-the-bye), and fail to find any points of difference, except that of size; the Rhretic specimen being about half as large again as the other, which agrees well with the Lyme Regis type figured by Agassiz.

RALPH TATE.

92, Crty Road, Bristol, May 19th, 1875.

1 See Mr. Poulett Scrope's critical examination of Mr. Mallet's paper in the Gror. Mag. for 1874, New Series, Decade II. Vol. I. pp. 529-542. See also Mr. J. W. Judd's artiele on Stromboli, Geox. Mag. 1875, Dec. II. Vol. II. No. V. for May, p. 210. 